\title{
Population and habitat assessment of the Critically Endangered hirola Beatragus hunteri in Tsavo East National Park, Kenya
}

\author{
James Probert, Ben Evans, Sam Andanje, Richard Kock and Rajan Amin
}

\begin{abstract}
The Critically Endangered hirola Beatragus hunteri exists in two populations, a natural population on the Kenyan-Somali border and a translocated population in Tsavo East National Park, Kenya. The Tsavo population is becoming increasingly important for the survival of the hirola yet its status is unknown and little is understood about the factors that limit its growth. Here we report the size, distribution and demographic parameters of the Tsavo population of hirola and consider whether insufficient suitable habitat could be limiting its growth. The Tsavo population has not increased since 2000, when the last census was carried out, but neither has it significantly decreased. The importance of habitat as a limiting factor is dependent on the hirola's ability to utilize marginal habitat.
\end{abstract}

Keywords Aerial survey, Beatragus hunteri, Critically Endangered, habitat suitability, hirola, Kenya, Tsavo East National Park, vegetation survey

\section{Introduction}

The hirola Beatragus hunteri (Sclater, 1889) is the sole 1 extant representative of a long-lasting phylogenetic lineage that originated c. 3.1 million years ago and the present population represents the last relic of a once widespread genus (Gentry, 1990; Pitra et al., 1998). Beatragus is now recognized as the most threatened monotypic genus of antelope (IUCN, 2011).

The global hirola population declined from 16,000 animals in the late 1970 s to an estimated 1,600 animals in 1988 (Ottichilo et al., 1995; Butynski, 1999) and now to an estimated 350-500 animals (Evans, 2011; King et al., 2011; Probert, 2011). There are no hirola in captivity (Butynski, 2000) and its extinction would be the first loss of a mammalian genus in Africa since the evolution of modern man (Gentry, 1990; King et al., 2011).

James Probert (Corresponding author) and Ben Evans Department of Life Sciences, Imperial College London, London, UK

E-mail jamesprobert@btinternet.com

Sam Andanje Ecosystem and Landscape Conservation Department, Kenya Wildlife Service, Nairobi, Kenya

Richard Kock Wildlife Diseases, Royal Veterinary College, North Mymms, UK

RAJAN Amin Conservation Programmes, Zoological Society of London, UK

Received 6 January 2013. Revision requested 26 February 2013.

Accepted 11 June 2013. First published online 22 May 2014.
The hirola's natural range has contracted and now comprises an area of no more than $1,500 \mathrm{~km}^{2}$ on the Kenyan-Somali border. As insurance against the possible failure of efforts to save the in situ population a translocated population was established in Kenya's Tsavo East National Park (Fig. 1), with translocations in 1963 and 1996 (Hofmann, 1996; Andanje \& Ottichilo, 1999; Butynski, 1999; East, 1999).

Since the 1996 translocation the Tsavo population has remained stable and no further efforts have been made to increase it. The factors limiting the size of the population and influencing the distribution of hirola in Tsavo are not well understood. This prevents effective planning of conservation management (Butynski, 2000; Andanje, 2002).

The hirola population in Tsavo is currently estimated to be 76 individuals, or c. $15 \%$ of the global population (K. Kimitei, pers. comm.). The last census was in 2000 but a severe drought in 2008 and 2009 that affected other ungulate species in the region severely may also have affected the hirola population (Probert, 2011).

\section{Methods}

\section{Ground and aerial surveys}

The original survey method was based on systematic aerial surveys coordinated with ground surveys to facilitate a comparison of counts and calculation of confidence intervals. However, this had to be modified because mechanical problems and difficulties obtaining aviation fuel prevented the ground and aerial surveys running concurrently. We conducted an intensive ground survey during 6 May-17 June 2011, followed by an aerial survey during 30 June-5 July 2011.

The ground survey was carried out in a single vehicle by a team of three researchers and a park ranger. To maximize the likelihood of finding hirola we used data from the Kenya Wildlife Service Hirola Monitoring Programme to identify locations of previous sightings and collected information on recent sightings from safari guides and drivers. On completion of the study the identification sheet we created for drivers and guides was expanded into a hirola identification guide.

We conducted daily surveys, during $06.30-10.00$ and 15.00-18.00, driving on- and off-road transects through areas where hirola had been reported. We also recorded 


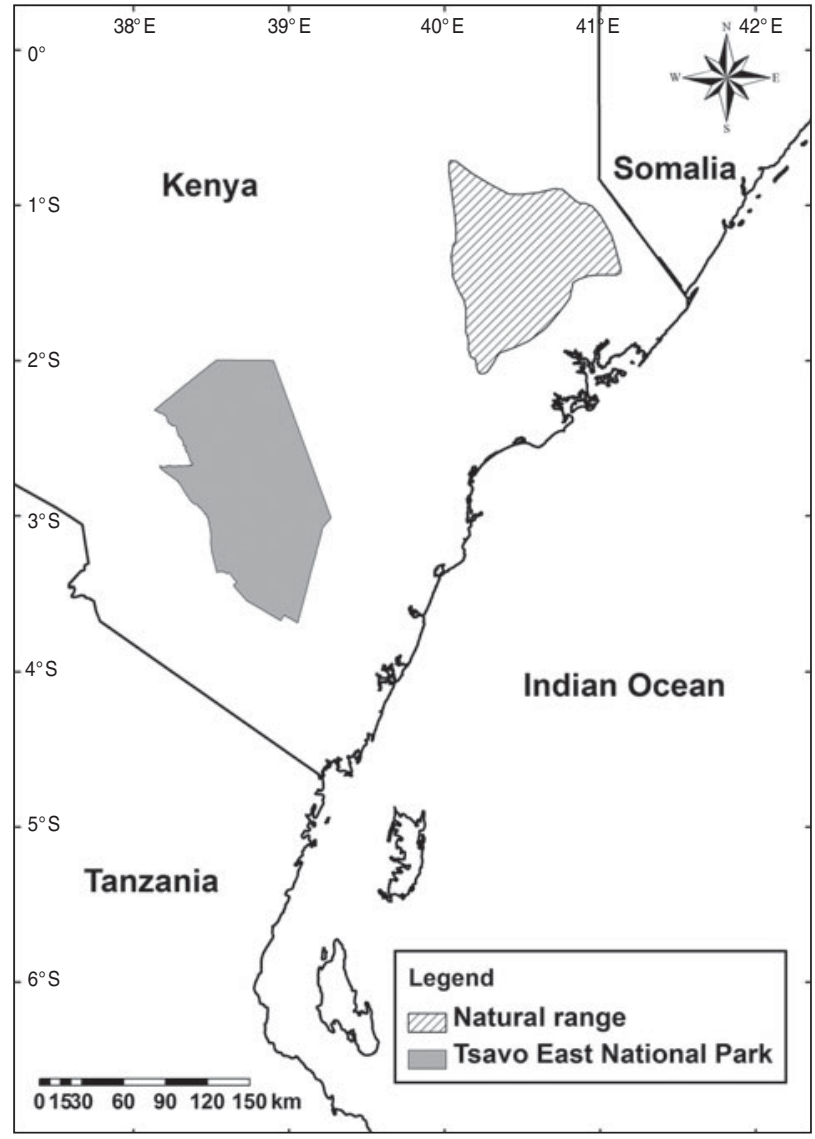

FIG. 1 The natural range of the hirola Beatragus hunteri (IUCN, 2008), and Tsavo East National Park, Kenya, where the translocated population is located.

opportunistic sightings of hirola while driving around Tsavo. We recorded locations where hirola were present, using a global positioning system (GPS), and collected data on herd demographics. We maintained a minimum distance of $30 \mathrm{~m}$ from herds to avoid disturbing the animals and potentially scattering the herd.

We used a standardized age-class system based on horn development (Andanje, 2002). This consisted of four age classes: calf ( $0-3$ months), individual without horns or with horns just protruding; juvenile (4-9 months), individual with straight horns up to or just exceeding ear length; subadult (10-18 months), individual whose horn tips had started pointing inwards, widening from the centre and forming an oval shape; and adult ( $>18$ months), individual with spread out, mature horns.

Male and female hirola are almost identical in appearance and therefore sexing them is difficult. Males are slightly larger and darker than females, the testicles are high between the thighs and the penile sheath is barely visible. It is easiest to determine a hirola's sex when the animal is urinating, walking directly away from the observer or raising a hind leg (Andanje, 2002). We observed behaviour for further indications of sex (e.g. attempts at mounting, scent marking and pawing the ground). Only adult and subadult hirola were sexed.

The aerial survey was conducted over 12 days, in a Piper Super Cub aircraft with a pilot and a single observer on board. The plane flew transects spaced $500 \mathrm{~m}$ apart at an altitude of 61-122 $\mathrm{m}$ and a speed of $130 \mathrm{~km} \mathrm{~h}^{-1}$. The observer recorded hirola within $200 \mathrm{~m}$ either side of the transect, with the date and time of the observation, and saved the location as a waypoint on a GPS.

We conducted aerial surveys during the cooler times of the day (06.00-10.00 and 15.30-18.00), when the animals are most active and are easier to spot because of the angle of the sunlight. Aircraft tracks were logged using a GPS and downloaded to ensure the entire survey area was covered. A ground team confirmed sightings and recorded data on herd structure and individual identification.

\section{Vegetation surveys}

For every sighting of hirola during the ground survey where the location of the herd could be determined accurately we carried out a vegetation survey, in a $20 \times 20 \mathrm{~m}$ plot oriented north-south, with a $1-\mathrm{m}^{2}$ quadrat in the centre. This method followed Andanje (2002), to facilitate comparisons. The position of the plot was recorded using a GPS, with the date and time and the reference number for the sighting.

Within each plot we estimated grass cover and categorized shrubs, bushes and trees according to height and width. Trees or bushes $\geqslant 1.8 \mathrm{~m}$ high and $\geqslant 5 \mathrm{~m}$ wide were identified to species level. We counted grass tufts and forbs within the quadrat and identified them to species level. We retained samples of grasses, forbs and trees for future reference.

A grass tuft was defined as a grouping of leaves and inflorescences arising from a single root base. Where a grass used rhizomes for reproduction any tuft along the rhizome that had taken root was classified as a separate tuft. A forb was defined as any herbaceous plant in the understorey. A bush or tree was defined as any plant with a woody stem that rose above the level of the surrounding grasses and forbs (Andanje, 2002). We included bushes and grass tufts on the boundary of the plot in our count.

\section{Data analysis}

We carried out statistical analyses using $R \quad$ v. 2.13 .1 ( $\mathrm{R}$ Development Core Team, 2012). We used an online red-listing tool (Kew Royal Botanic Gardens, 2011) to calculate the extent of occurrence and area of occupancy of the hirola population in Tsavo, and used the standard cell size for IUCN assessments $\left(2 \mathrm{~km}^{2}\right)$ to calculate the area of occupancy.

We used MaxEnt v. 3.3.3k (Phillips et al., 2004, 2006) to model habitat suitability for hirola based on the species' 
distribution. We chose MaxEnt because it requires presence-only data, can deal with relatively few data points and both categorical and continuous variables, and performs well compared to other methods (Phillips et al., 2006) and when predictions have been verified on the ground (Rebelo \& Jones, 2010).

The model inputs were species presence data in simple text format and a set of seven environmental layers in the form of raster grids, converted to ASCII format. The environmental layers were from two sources: Kenya Wildlife Service provided geographical information system shape files for vegetation type, soil type, geology and land cover, and we obtained layers for precipitation, elevation and temperature in raster format, with a cell size of 30 arcseconds $\left(\right.$ c. $\left.1 \mathrm{~km}^{2}\right)$ from WorldClim (Hijmans et al., 2005). Mean annual values were used for the precipitation and temperature layers.

We imported the environmental layers into ArcMap v. 9.3 (ESRI, Redlands, USA), transformed them to the same coordinate system and clipped them to the same extent. The shape files were transformed into raster grids and all layers were converted to ASCII format for importing into MaxEnt. The cell size of the shape files when they were converted to raster grids was dictated by the cell size of the WorldClim environmental layers.

We created the habitat suitability model in two stages. Firstly, to verify that the model predicted hirola distribution accurately, we used $80 \%$ of the presence data to train a model that was then tested using the remaining $20 \%$ of the data. MaxEnt tests the accuracy of a model by calculating the omission rate and the area under the receiver operating curve (AUC). An AUC value of $\geqslant 0.75$ is considered necessary for an accurate model (Elith, 2002). We crossvalidated the model, using the mean values of four replicates of 500 iterations each. For each replicate we selected at random a new set of presence points for testing. When we had confirmed the accuracy of the model we created the final model using all the presence data.

\section{Results}

\section{Distribution and abundance}

The ground survey covered $>7,000 \mathrm{~km}$ of transects in 213 hours. We sighted hirola on 32 occasions; we observed 42-52 hirola and estimate the actual number to be 45 . This uncertainty is a result of the fission-fusion dynamics of hirola herds. Individual hirola were sometimes sighted in an area where a herd was commonly seen and it was unclear whether it was a new individual or a previously counted member of the herd.

The aerial survey covered an area of c. $3,780 \mathrm{~km}^{2}$, with hirola sighted on 11 occasions and 76 individuals recorded. The ground team confirmed six sightings and 47

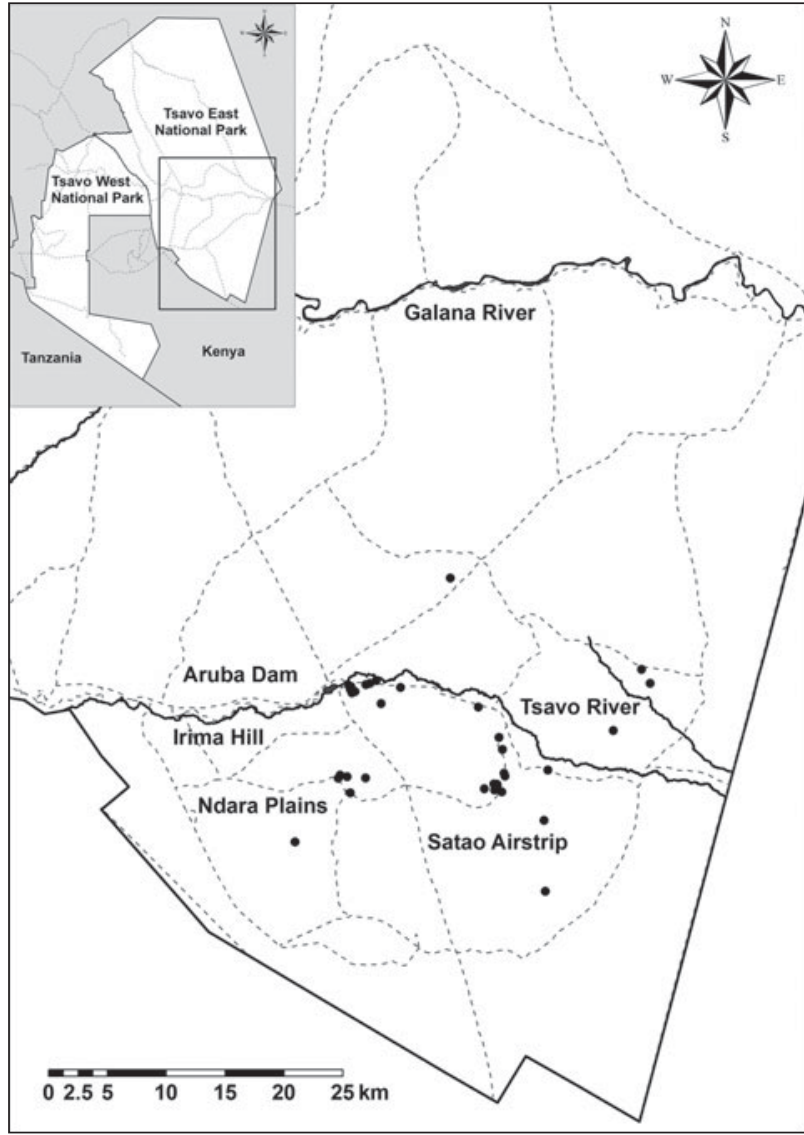

FIG. 2 The locations of hirola sightings in Tsavo East National Park (Fig. 1). Sightings are indicated by filled circles and roads by dashed lines. The rectangle on the inset indicates the location of the main map in Tsavo East National Park.

individuals. Based on individual identification, 25 of these 47 hirola had been sighted during the ground survey. The combined sightings from ground and aerial surveys yielded a count of 67 individuals. The estimated extent of occurrence of the hirola in Tsavo was $500 \mathrm{~km}^{2}$, calculated by fitting a minimum convex polygon to the locations where hirola were sighted. The estimated area of occupancy was $76 \mathrm{~km}^{2}$ (Fig. 2).

There were insufficient sightings of any herd to estimate the home range. Herds were generally sedentary; the longest distance travelled was $4.3 \mathrm{~km}$ in 64 hours. The longest distance between concurrent sightings of the same herd was $11.8 \mathrm{~km}$ in 624 hours (26 days).

\section{Population and group structure}

The mean herd size was 6.6 (range $2-14, n=10$ ), the mean size of nursery herds was 9.8 (range $6-14, \mathrm{n}=5$ ) and the mean size of bachelor herds was 3.8 (range $2-6, n=4$ ). We observed five nursery herds, four bachelor herds, one lone male and a pair of females (Table 1).

We identified 46 adults, 6 subadults, 14 juveniles and 1 calf. The male: female ratio in adults and subadults was 
TABle 1 Herd composition of the hirola Beatragus hunteri population in Tsavo East National Park, Kenya (Fig. 1), by age class and sex.

\begin{tabular}{|c|c|c|c|c|c|c|c|}
\hline \multirow[b]{2}{*}{ Herd } & \multicolumn{2}{|c|}{ Adults } & \multicolumn{2}{|c|}{ Subadults } & \multirow[b]{2}{*}{ Juveniles } & \multirow[b]{2}{*}{ Calves } & \multirow[b]{2}{*}{ Total } \\
\hline & Male & Female & Male & Female & & & \\
\hline Nursery 1 & 2 & 7 & & & 5 & & 14 \\
\hline Nursery 2 & 1 & 4 & & & 2 & & 7 \\
\hline Nursery 3 & 1 & 7 & & & 3 & 1 & 12 \\
\hline Nursery 4 & 1 & 4 & & & 1 & & 6 \\
\hline Nursery 5 & 1 & 6 & & & 3 & & 10 \\
\hline Lone male & 1 & & & & & & 1 \\
\hline Lone female & & 2 & & & & & 2 \\
\hline Bachelor 1 & & & 3 & & & & 3 \\
\hline Bachelor 2 & 6 & & & & & & 6 \\
\hline Bachelor 3 & 2 & & & & & & 2 \\
\hline Bachelor 4 & 1 & & 3 & & & & 4 \\
\hline Total & 16 & 30 & 6 & 0 & 14 & 1 & 67 \\
\hline
\end{tabular}

$1: 1.36$ (22 males and 30 females). Sex ratio (expressed as a percentage of the total) did not differ significantly from the sex ratio of calves born in captivity; e.g. Gladys Porter Zoo (Brownsville, USA; $\chi^{2}=3.13, \mathrm{df}=1, \mathrm{P}=0.077$ ), Dvůr Králové Zoo (Dvůr Králové nad Labem, Czech Republic; $\left.\chi^{2}=0.90, \mathrm{df}=1, \mathrm{P}=0.342\right)$ or the sum of both zoos $\left(\chi^{2}=0.08, \quad \mathrm{df}=1, \mathrm{P}=0.777 ;\right.$ Smielowski, 1987; Gladys Porter Zoo, pers. comm.). Of the 22 males observed six were accompanying a nursery herd and 16 were either alone or in a bachelor herd.

The age structure of the hirola population can be used as an indicator of mortality in different age classes. Peak calving season is during September-November, and therefore at the time of this study the previous year's cohort of calves was 6 months old and the cohort from the year before was 18 months old (Andanje, 2002).

Of the observed hirola $68.6 \%$ were adults, $9.0 \%$ subadults, $20.9 \%$ juveniles and $1.5 \%$ calves $(n=67) ; 30$ of the adults were female. Assuming that each adult female produced one calf, estimated mortality in the first 6 months of life is $50 \%$. Assuming that the number of breeding females is constant from year to year, estimated mortality in the first 18 months is $80 \%$.

\section{Vegetation surveys and habitat classification}

On three occasions during the ground survey we could not determine the precise location of hirola and therefore did not conduct a vegetation survey. On one occasion a herd was so spread out that three vegetation surveys were carried out for a single sighting. Overall 31 vegetation surveys were carried out, corresponding to 29 sightings of hirola.

Hirola were found at altitudes of 338-436 m. Mean grass cover was $66 \%$ (range 5-95\%). We identified 20 species of grass, the most common being Tetrapogon bidentatus, with Brachiaria serrata occurring at the highest density (Table 2).

We identified six species of forb, of which Hermannia spp. (Sterculiaceae) and Blepharis linariifolia were the most common and B. linariifolia occurred at the highest density (Table 3).

There were only two trees $\geqslant 1.8 \mathrm{~m}$ tall and $\geqslant 5 \mathrm{~m}$ wide in the vegetation plots, both Acacia tortilis. Bushes $\geqslant 1.8 \mathrm{~m}$ tall and $<5 \mathrm{~m}$ wide were found at a density of one per $387.5 \mathrm{~m}^{2}$ and bushes $<1.8 \mathrm{~m}$ tall and $<5 \mathrm{~m}$ at a density of one per $62 \mathrm{~m}^{2}$. There were no bushes $<1.8 \mathrm{~m}$ tall and $\geqslant 5 \mathrm{~m}$ wide.

In general we observed hirola in savannah with trees and bushes. The vegetation was largely undifferentiated floodplain vegetation but there were areas of Acacia-Commiphora, Commiphora-Lannea, AcaciaSchoenefeldia and variants. The geology of these areas, extracted from the shapefiles provided by Kenya Wildlife Service, included unconsolidated clay and sand, loam, arkose, phonolite, shale, siltstone, crystalline limestone, hornblende/biotite gneiss and fine-to-coarse-grained sandstone.

\section{Habitat suitability modelling}

The mean AUC over the four replicate models was 0.81 and the omission rate did not differ significantly from predicted values. This indicates that the test data fitted the distribution predicted by the model. The habitat suitability map calculated using the complete dataset is shown in Fig. 3.

Soil type contributed most to the model (77.0\%), followed by precipitation $(8.2 \%)$, geology $(7.6 \%)$, elevation (4.5\%), land cover (1.9\%), vegetation type (0.5\%) and temperature $(0.3 \%)$. Soil type was also the layer that decreased gain most significantly when it was omitted from the model.

\section{Discussion}

Our results indicate that there is a small but stable population of hirola in Tsavo East National Park. Surveys in 1995 and 2000 estimated the population to be 76 and 77, respectively (Andanje, 1997, 2002; Butynski, 2000). 
TABLE 2 Grass species present in areas where hirola were observed.

\begin{tabular}{|c|c|c|c|c|}
\hline Grass species & $\begin{array}{l}\text { No. of quadrats with } \\
\text { species present }\end{array}$ & $\begin{array}{l}\% \text { quadrats with } \\
\text { species present }\end{array}$ & No. of tufts & 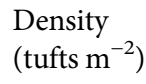 \\
\hline Tetrapogon bidentatus & 16 & 52 & 99 & 6.2 \\
\hline Leptothrium senegalense & 14 & 45 & 77 & 5.5 \\
\hline Chloris roxburghiana & 10 & 32 & 28 & 2.8 \\
\hline Tetrapogon tenellus & 8 & 26 & 102 & 12.8 \\
\hline Cenchrus ciliaris & 6 & 19 & 9 & 1.5 \\
\hline Brachiaria serrata & 4 & 13 & 259 & 64.8 \\
\hline Panicum deustum & 4 & 13 & 29 & 7.3 \\
\hline Schmidtia pappophoroides & 4 & 13 & 10 & 2.5 \\
\hline Tetrapogon cenchriformis & 4 & 13 & 6 & 1.5 \\
\hline Chloris virgata & 3 & 10 & 3 & 1.0 \\
\hline Brachiaria deflexa & 2 & 6 & 13 & 6.5 \\
\hline Urochloa mosambicensis & 2 & 6 & 2 & 1.0 \\
\hline Eragrostis caespitosa & 2 & 6 & 3 & 1.5 \\
\hline Echinochloa colona & 1 & 3 & 4 & 4.0 \\
\hline Eragrostis volkensii & 1 & 3 & 6 & 6.0 \\
\hline Aristida mollissima & 1 & 3 & 1 & 1.0 \\
\hline Eragrostis racemosa & 1 & 3 & 1 & 1.0 \\
\hline Tragus berteronianus & 1 & 3 & 1 & 1.0 \\
\hline Dactyloctenium aegyptium & 1 & 3 & 1 & 1.0 \\
\hline Eragrostis cilianensis & 1 & 3 & 4 & 4.0 \\
\hline
\end{tabular}

TABLE 3 Forb species present in areas where hirola were observed.

\begin{tabular}{|c|c|c|c|c|}
\hline Forb species & $\begin{array}{l}\text { No. of quadrats with } \\
\text { species present }\end{array}$ & $\begin{array}{l}\% \text { quadrats with } \\
\text { species present }\end{array}$ & No. of plants & 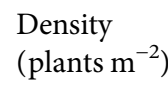 \\
\hline Hermannia spp. & 5 & 15.6 & 20 & 4.0 \\
\hline Blepharis linariifolia & 5 & 15.6 & 59 & 11.8 \\
\hline Tephrosia villosa & 4 & 12.5 & 8 & 2.0 \\
\hline Unidentified & 3 & 9.4 & 4 & 1.3 \\
\hline Solanum dubium & 2 & 6.3 & 7 & 3.5 \\
\hline Digera muricata & 2 & 6.3 & 2 & 1.0 \\
\hline
\end{tabular}

The drought in 2008 and 2009 does not appear to have caused the high level of mortality predicted by Amin \& Andanje (2011).

It has been reported that male hirola are predated more frequently than females (Andanje, 2002) but our results show that the sex ratio of adult and subadult hirola in Tsavo does not differ significantly from the sex ratio of calves born in captivity, indicating the rate of mortality is the same for male and female hirola in Tsavo.

Andanje (2002) found that the male:female ratio in adults and subadults varied between $1: 2.6$ and $1: 3.0$ (male:female) depending on the time of year. The difference between those results and the sex ratio of 1:1.36 found in this study is a result of a reduction in the number of females rather than an increase in the number of males. The reasons are unknown but it may be an Allee effect. We found smaller herds than reported historically and these herds may be less able to share the costs of vigilance and may therefore be more vulnerable to predation (Andanje, 2002).
The polygynous social system of the hirola means that females are likely to mate every year but it is unlikely that all females will produce a calf every year. Consequently the predicted mortality figures are a worst-case scenario. They support previous findings that mortality is highest at c. 9 months old, when hirola disperse from their natal herd (Andanje, 2002).

There is now a substantial body of information on the habitats occupied by hirola in Tsavo. Eleven species of grass (55\%) and two species of forbs (33\%) found in this study are eaten by hirola (Andanje, 2002).

Hirola mainly occupy savannah habitats with varying degrees of bush cover. Such habitats exist on a variety of rock and soil types throughout Tsavo, mostly concentrated around Satao and the Aruba Dam. The release sites for the 1963 translocation were at the Ndara Plains and Irima Hill. Both areas have black cotton soil, which becomes waterlogged and flooded during the wet season. At an altitude of $600 \mathrm{~m}$, Irima is higher than the current altitude 


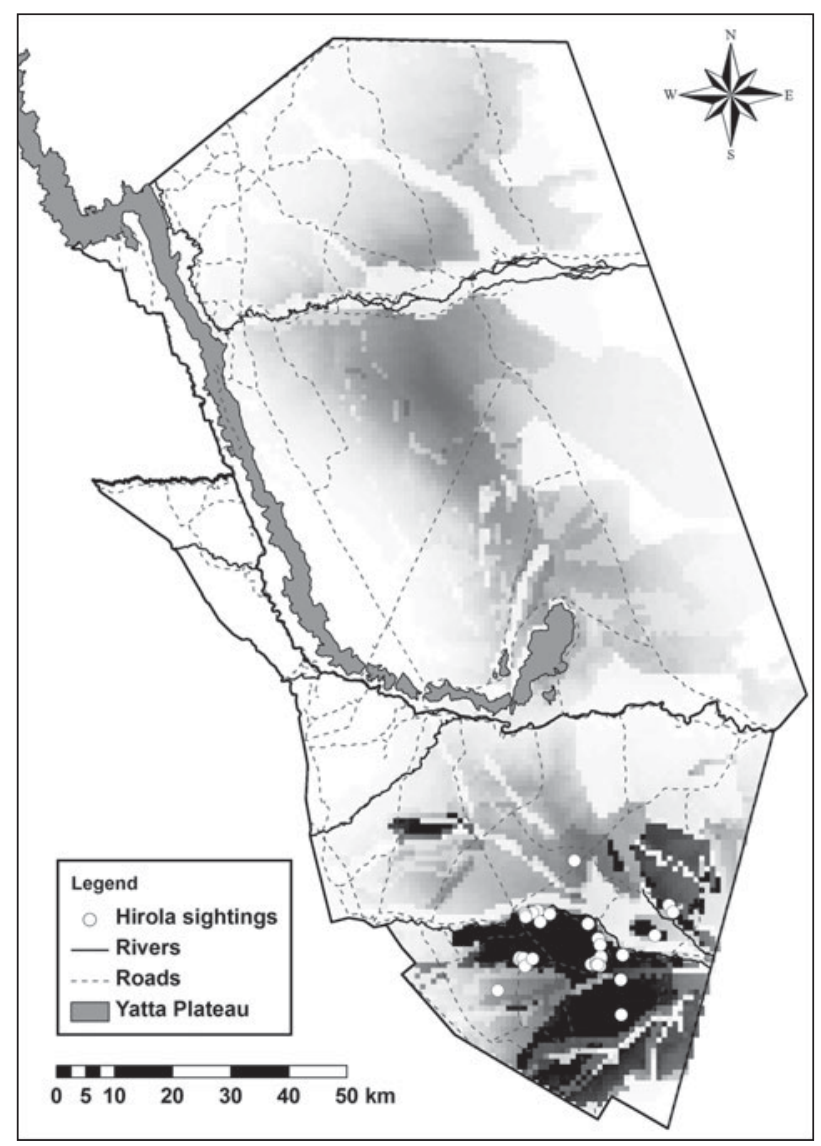

FIG. 3 Predicted habitat suitability for hirola across Tsavo East National Park (Fig. 1). The darker shading represents more suitable habitat.

of hirola range and the vegetation of Ndara and Irima largely comprises tall grass, with areas of thick bush. The current range is predominantly on red sandy soils, with sparse, scattered bush and shorter grass (Andanje, 2002). The distribution and extent of occurrence of the hirola population do not appear to have changed significantly since they were mapped by Andanje \& Goeltenboth (1995) and Andanje (2002).

The habitat suitability model shows that the areas around the Aruba Dam are the most suitable for hirola. Predicted habitat suitability depends on the extremes of the variables within the study area. For an absolute measure of the suitability of Tsavo East a comparison needs to be made with the environmental conditions and habitat in the hirola's natural range. This will be challenging as the species' distribution in its natural range is less influenced by environmental variables and more by the distribution and behaviour of humans and livestock and by bush encroachment resulting from the poaching of elephants.

Our model is only pertinent to the wet season. To understand fully the habitat requirements of hirola in Tsavo a model needs to be created using distribution data from the dry season. Even then modelling may not be able to truly capture the relationship between hirola and precipitation. As with other ungulate species the hirola is mobile and dependent on the availability of short, green grass, which results from spatially and temporally irregular rainfalls (Ben-Shahar \& Coe, 1992; Andanje, 2002; Georgiadis et al., 2003). The mean rainfall values generated by WorldClim are insufficiently sensitive to detect local rainfall patterns.

Although soil type contributed most to the model it is unlikely that it affects the distribution of hirola directly. It determines factors such as bush cover and grass species occurrence through properties such as moisture retention, runoff and nutrient content. The two layers relating to vegetation included in the model were not oriented towards grass species, and the distribution of grass species and communities would be valuable additions to the model.

Depending on the hirola's ability to utilize marginal habitat (which is currently unknown) it is possible that an increasing population would expand into new areas of Tsavo. Equally the population may be limited by the extent of suitable habitat, which would explain why it has been stagnant for decades. Further habitat suitability modelling could help predict the effects of climate change on environmental conditions and their implications for hirola conservation.

A comprehensive evaluation of the conservation status of the hirola is compromised by the lack of up-to-date data. We generated a baseline dataset for distribution and abundance and it is essential that this is replicated at annual intervals to assess trends, using a standardized method.

We have established that the Tsavo population is stable but further research is required to provide information needed to make effective management decisions. In light of this and the decline of the hirola in its natural range the emphasis of hirola conservation in Tsavo should be on effective monitoring; however, most conservation efforts continue to be directed towards reversing the decline of the natural population. This is being done through an established sanctuary at Ishaqbini and a predator-proof fenced sanctuary to the south-east. These conservation areas are managed by the local community, with support from the Northern Rangelands Trust and Kenya Wildlife Service. Early indicators are positive but given the decreased range, population fragmentation and future habitat degradation the long-term future of the hirola remains uncertain. The Tsavo population therefore remains significant and deserving of conservation effort.

\section{Acknowledgements}

We thank Dr Shadrack Ngene, Kenneth Kimitei, Haustings Syengo and security rangers Hillary Rotich, Ahmed Wako and Enok Kirwa for their help in Tsavo and Dr Thomas deMaar and Diana Lucio for kindly answering our questions. A donation from the Zoological Society for the 
Conservation of Species and Populations covered fuel costs and Kenya Wildlife Service waived park fees. Mike Kirkland, Raymond Behr, Paul Ndanga, Jiti Basil and Mr Opio kindly allowed us to stay at Satao Camp and Lion Hill Camp for the duration of our fieldwork. We thank Rod and Debbie Evans for providing us with a vehicle for our fieldwork and for their generous hospitality in Nairobi.

\section{References}

Amin, R. \& Andanje, S. (2011) Monitoring and Recovery of the Tsavo Hirola. Unpublished report.

Andanje, S.A. (1997) Hirola Monitoring Progress Report: Update Analysis of Animal Movement, Location and Herding. Biodiversity Conservation Unit, Kenya Wildlife Service, Nairobi, Kenya.

Andanje, S.A. (2002) Factors limiting the abundance and distribution of hirola (Beatragus hunteri) in Kenya. $\mathrm{PhD}$ thesis. Newcastle University, Newcastle, UK.

Andanje, S.A. \& Goeltenboth, P. (1995) Aspects of the Ecology of the Hunter's Antelope or Hirola (Beatragus hunteri, Sclater, 1889) in Tsavo East National Park, Kenya. Research and Planning Unit, Kenya Wildlife Service, Nairobi, Kenya.

Andanje, S.A. \& Otтichilo, W.K. (1999) Population status and feeding habits of the translocated sub-population of Hunter's antelope or hirola (Beatragus hunteri, Sclater, 1889) in Tsavo East National Park, Kenya. African Journal of Ecology, 37, $38-48$.

Ben-Shahar, R. \& Coe, M.J. (1992) The relationships between soil factors, grass nutrients and the foraging behaviour of wildebeest and zebra. Oecologia, 90, 422-428.

Butynski, T.M. (1999) Aberdare National Park and Aberdare Forest Reserves Wildife Fence Placement Study and Recommendations. Unpublished report. Kenya Wildlife Service and Kenya Forest Department, Nairobi, Kenya.

Butynski, T.M. (2000) Independent Evaluation of Hirola Antelope (Beatragus hunteri) Conservation Status and Conservation Action in Kenya. Kenya Wildlife Service and Hirola Management Committee, Nairobi, Kenya.

EAst, R. (1999) African Antelope Database 1998. IUCN/SSC Antelope Specialist Group, IUCN, Gland, Switzerland, and Cambridge, UK.

Elith, J. (2002) Quantitative methods for modeling species habitat: comparative performance and an application to Australian plants. In Quantitative Methods for Conservation Biology (eds S. Ferson \& M. Burgman), pp. 39-58. Springer-Verlag, New York, USA.

Evans, B. (2011) Assessing predation levels on the hirola antelope in Tsavo East National Park, Kenya. MSc thesis. Imperial College London, UK.

Gentry, A.W. (1990) Evolution and dispersal of African Bovidae. In Horns, Pronghorns and Antlers (eds G.A. Bubenik \& A.B. Bubenik), pp. 195-227. Springer-Verlag, New York, USA.

Georgiadis, N., Hack, M. \& Turpin, K. (2003) The influence of rainfall on zebra population dynamics: implications for management. Journal of Applied Ecology, 40, 125-136.

Hijmans, R.J., Cameron, S.E., Parra, J.L., Jones, P.G. \& JARVIS, A. (2005) Very high resolution interpolated climate surfaces for global land areas. International Journal of Climatology, $25,1965-1978$.

Hofmann, R.R. (1996) Hirola: translocation to Tsavo NP and new scientific information. Gnusletter, 15, 2-5.

IUCN (2008) Beatragus hunteri. In IUCN Red List of Threatened Species v.2013.2. Http://www.iucnredlist.org/ [accessed 6 May 2014].

IUCN (2011) IUCN Red List of Threatened Species v. 2011.1. Http:// www.iucnredlist.org/ [accessed March 2014].

Kew Royal Botanic Gardens (2011) Geospatial Conservation Assessment Tool. Http://geocat.kew.org/ [accessed August 2011].

King, J., Craig, I., Andanje, S. \& Musyoki, C. (2011) They came, they saw, they counted. SWARA, 34, 30-34.

Ottichilo, W.K., Mirangi, J.M., Muriuki, G. \& Kock, R. (1995) The Current Status of Hunter's Hartebeest (Hirola) in Kenya. Kenya Wildlife Service, Nairobi, Kenya.

Phillips, S.J., Anderson, R.P. \& Schapire, R.E. (2006) Maximum entropy modeling of species geographic distributions. Ecological Modeling, 190, 231-259.

Phillips, S.J., Duddik, M. \& Schapire, R.E. (2004) A maximum entropy approach to species distribution modeling. In Proceedings of the 21st International Conference on Machine Learning. ACM Press, New York, USA.

Pitra, C., Kock, R., Hofmann, R. \& Lieckfeldt, D. (1998) Molecular phylogeny of the Critically Endangered Hunter's antelope (Beatragus hunteri, Sclater 1889). Journal of Zoological Systematics and Evolutionary Research, 36, 179-184.

Probert, J. (2011) The Tsavo hirola: current status and future management. MSc thesis. Imperial College London, UK.

R Development Core Team (2012) R: A Language and Environment for Statistical Computing. R Foundation for Statistical Computing, Vienna, Austria.

Rebelo, H. \& Jones, G. (2010) Ground validation of presence-only modelling with rare species: a case study on barbastelles Barbastella barbastellus (Chiroptera: Vespertilionidae). Journal of Applied Ecology, 47, 410-420.

Sclater, P.L. (1889) Description of Hunter's antelope. Proceedings of the Zoological Society of London, 58, 372-377.

Smielowski, J. (1987) A note on the reproductive biology of the Hunter's antelope or hirola Damaliscus hunteri (Sclater, 1889) in the zoo environment. Zoologische Garten, 57, 234-240.

\section{Biographical sketches}

JAMES PROBERT is a researcher and conservationist interested in the ecology and management of threatened species and the interactions that shape ecological communities. BEN EVANS is a conservation scientist who has worked to combat elephant and rhino poaching in Chad. Sam Andanje has extensive research experience in Kenyan forest and savannah ecosystems, particularly with rare species of antelope including hirola and Aders' duiker. RICHARD KOCK has worked in conservation for over 34 years and his work has included establishing a veterinary department at Kenya Wildlife Service and making significant contributions to the eradication of rinderpest in Africa. RAJAN AMIN specializes in conservation and research of African and Asian grassland and forest ecosystems, and in developing long-term conservation projects for threatened species. 